\title{
Effect of the Hydrodynamic Conditions on the
}

\section{Electrochemical Degradation of Phenol on a BDD Anode}

\author{
S. Sobreira, M.J. Pacheco, L. Ciríaco and A. Lopes* \\ UMTP and Department of Chemistry, University of Beira Interior, 6201-001 Covilhã, Portugal
}

Received 3 January 2011; accepted 24 February 2011

\begin{abstract}
The influence of the hydrodynamics of the system on the extent of the electrochemical degradation of phenol, using a boron doped diamond (BDD) anode was investigated. Two different electrochemical cells were used: a batch stirred cell (A), with a volume of $200 \mathrm{~mL}$ and a BDD anode of $17.5 \mathrm{~cm}^{2}$, and a batch with recirculation cell (B), with a BDD anode of $70 \mathrm{~cm}^{2}$ and connected to a tank of $30 \mathrm{~L}$. Assays were performed at different stirring speeds and applied current density of $300 \mathrm{~A} \mathrm{~m}^{-2}$, for cell $\mathrm{A}$, and various flow rates, with an imposed current density of $100 \mathrm{~A} \mathrm{~m}^{-2}$, for cell B. Chemical oxygen demand (COD) and total organic carbon (TOC) tests were performed to the samples collected throughout the assays, as well as UV-Vis spectrophotometric measurements. For cell A, after $2 \mathrm{~h}$ assay, COD removals between 84 and $94 \%$ and TOC removals ranging from 54 and $86 \%$ were attained. For the assays run with cell B, during $10 \mathrm{~h}, \mathrm{COD}$ and TOC removals varied from 27 to $51 \%$ and from 23 to $46 \%$, respectively. The influence of the turbulence near the electrode's surface in the combustion efficiency was also analysed.
\end{abstract}

Keywords: phenol; boron doped diamond electrode; electrochemical oxidation; hydrodynamic conditions.

\section{Introduction}

Phenol is one of the pollutants whose degradation has been under intense study in the last decades. In fact, it is often chosen as model pollutant. G. Busca and collaborators presented an extensive review over the different ways to promote its degradation [1].

Electrochemical oxidation of effluents containing persistent organic pollutants is an alternative or tertiary treatment that has received much attention in the last years due to its interesting characteristics, since it is a clean process, can operate at low temperature and, in most cases, without adding any chemical and without

\footnotetext{
* Corresponding author. E-mail address: analopes@ubi.pt
} 
sludge formation. Recently, the use of boron doped diamond (BDD) as anode material has proved to be very useful, since, besides its good mechanical and electrochemical stability, it has unique electrochemical characteristics, like large potential window for water decomposition [2], ability to produce hydroxyl radicals [3] poorly adsorbed on the electrode's surface [4] and that can perform the oxidation of the pollutants simultaneously in the bulk of the solution. Therefore, BDD anodes are an excellent material for the oxidation of all kinds of pollutants [5]. In particular, the electrooxidation of phenol and other phenolic compounds has already been carried out with BDD anodes, at bench scale, with good degradation rate [6,7]. However, to scale-up the process to an industrial level, a better understanding of the mass transfer during the electrochemical process is needed. The objective of this work is to study the influence of the hydrodynamic conditions on the mass transfer process during the anodic oxidation of phenol, using BDD as anode material, in two different electrochemical cells: a small batch stirred cell and a pilot cell with re-circulating flow.

\section{Experimental}

Two sets of electrochemical assays were run, using different experimental setups. The first one (A) consisted of an electrochemical cell, with a BDD anode of $17.5 \mathrm{~cm}^{2}$ area, purchased from Adamant Technologies/CSEM, Switzerland, and the degradation was carried out in batch mode, for $2 \mathrm{~h}$, at several stirring rates, using $200 \mathrm{~mL}$ of an aqueous $0.035 \mathrm{M} \mathrm{Na}_{2} \mathrm{SO}_{4}$ solution, containing $300 \mathrm{mg} \mathrm{L}^{-1}$ of phenol (purchased from Aldrich). Current was imposed by a laboratory power supply GW, model GPS-3O3OD. Cell B was a DiaCel 196PVDF, with two monopol BDD electrodes $\left(70 \mathrm{~cm}^{2}\right.$ area), from Adamant Technologies/CSEM, Switzerland, used with a Power supply DiaCell, PC-1500. These assays were performed in batch with recirculation mode, for $10 \mathrm{~h}$, and a centrifugal pump, Wilo, Serie MHI, enabled the recirculation of the solution at the different flow rates tested. The composition of the solution was identical of that in cell A, but a volume of $30 \mathrm{~L}$ was used here and re-circulation flow rates of 200, 300 and 500 $\mathrm{L} \mathrm{h}^{-1}$ were tested.

The electrochemical assays were performed in galvanostatic mode, at imposed current densities of 300 and $100 \mathrm{~A} \mathrm{~m}^{-2}$ for cells A and $\mathrm{B}$, respectively. Phenol degradation tests were followed by UV-Visible spectrophotometry, with

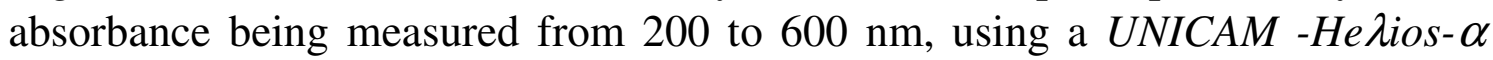
$U V / V I S$ spectrophotometer, by Chemical Oxygen Demand (COD) tests, using the closed reflux dichromate titrimetric method [8], and by Total Organic Carbon (TOC) determinations, performed in a Shimadzu TOC- $\mathrm{V}_{\mathrm{CPH}}$ apparatus. 


\section{Results and discussion COD analysis}

Fig. 1 presents the experimental COD removal as a function of the assays' duration, for the different experimental conditions tested with both electrochemical cells. In the case of the assays performed with cell $\mathrm{A}$, at the applied current density of $30 \mathrm{~A} \mathrm{~m}^{-2}$, the electrodegradation is diffusion controlled and COD follows an exponential decay, according to equation [9]:

$$
\mathrm{COD}=\mathrm{COD}_{0} \mathrm{e}^{-\frac{\mathrm{k}_{\mathrm{d}} \mathrm{At}}{\mathrm{v}}}
$$

where $\mathrm{COD}_{0}$ refers to the initial $\mathrm{COD}, \mathrm{A}, \mathrm{V}$ and $\mathrm{t}$ are the area of the electrode, the volume of the solution and the time, respectively, and $k_{d}$ is the medium mass transfer coefficient. This exponential equation was fitted to experimental data up to $90 \mathrm{~min}$, since after that period of time experimental data differs from fitted equation. This fact must be due to an incomplete combustion that leads to the formation and accumulation of new metabolites, with a different $k_{d}$. The $k_{d}$ values, determined from the fittings depicted in Fig. 1 (Cell A), are presented in Table 1, showing that an increase in the stirring rate leads to an increase in the medium mass transfer coefficient, probably due to a decrease in the width of the diffusion layer.
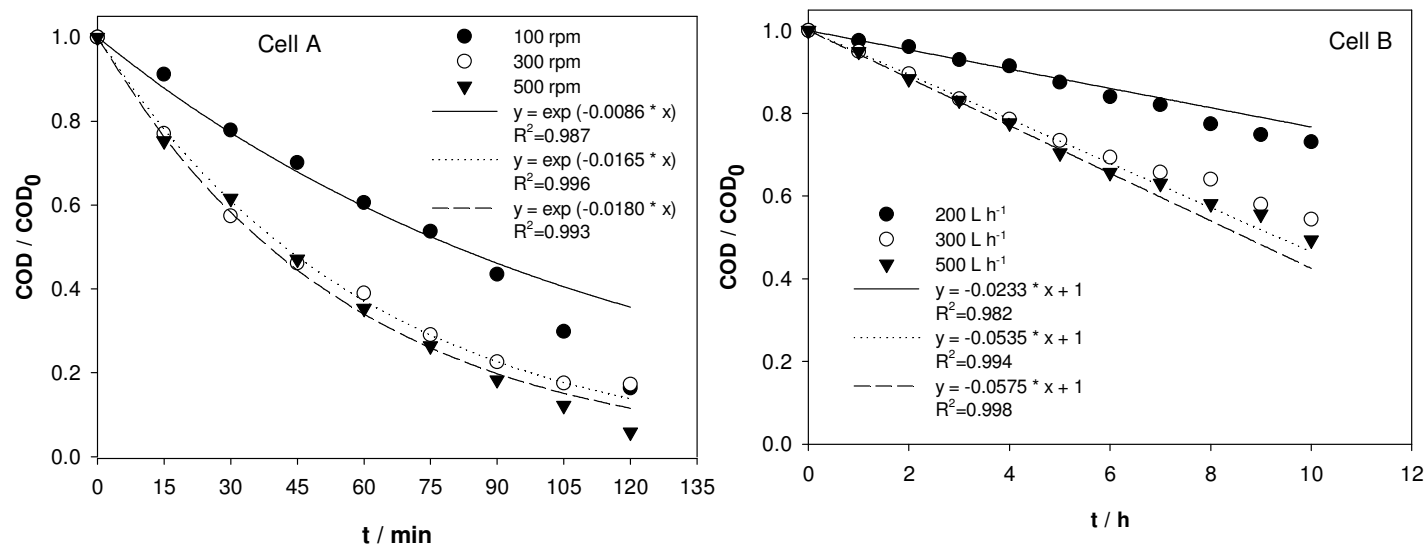

Figure 1. COD relative removal $v s$. time for the electrochemical degradation of phenol performed in cell $\mathrm{A}$, at different stirring rates and applied current density of $30 \mathrm{~A} \mathrm{~m}^{-2}$, and in cell $\mathrm{B}$, at different re-circulation flow rates and applied current density of $10 \mathrm{~A}$ $\mathrm{m}^{-2}$. Phenol initial concentration: $300 \mathrm{ppm}$; electrolyte: $0.035 \mathrm{M} \mathrm{Na}_{2} \mathrm{SO}_{4}$ aqueous solution.

Regarding the assays performed with cell $\mathrm{B}$, at $100 \mathrm{~A} \mathrm{~m}^{-2}$, the COD decay follows a linear fitting, typical from a current controlled process. However, in the fitting of linear equations to experimental results different slopes were obtained, which was not expected, since current intensity did not vary. The lower COD decay observed for the lower flow rate must be related with the formation of metabolites that may polarize the surface of the electrode, being removed more easily with the increase in flow rate. Also, in these assays, after an initial period, 
there is a change in the trend of COD decay, pointing out to an incomplete combustion of phenol, with the consequent formation of metabolites.

Table 1. Removals of COD, TOC and Abs, measured at 210 and $270 \mathrm{~nm}$, for the assays performed with cells $\mathrm{A}$ and $\mathrm{B}$, after $2 \mathrm{~h}$ and $10 \mathrm{~h}$ run, respectively, as well as medium mass transfer coefficients, $\mathrm{k}_{\mathrm{d}}$, determined for cell $\mathrm{A}$, and combustion efficiencies, $\eta_{\mathrm{c}}$, calculated for cells A and B at the different experimental conditions tested.

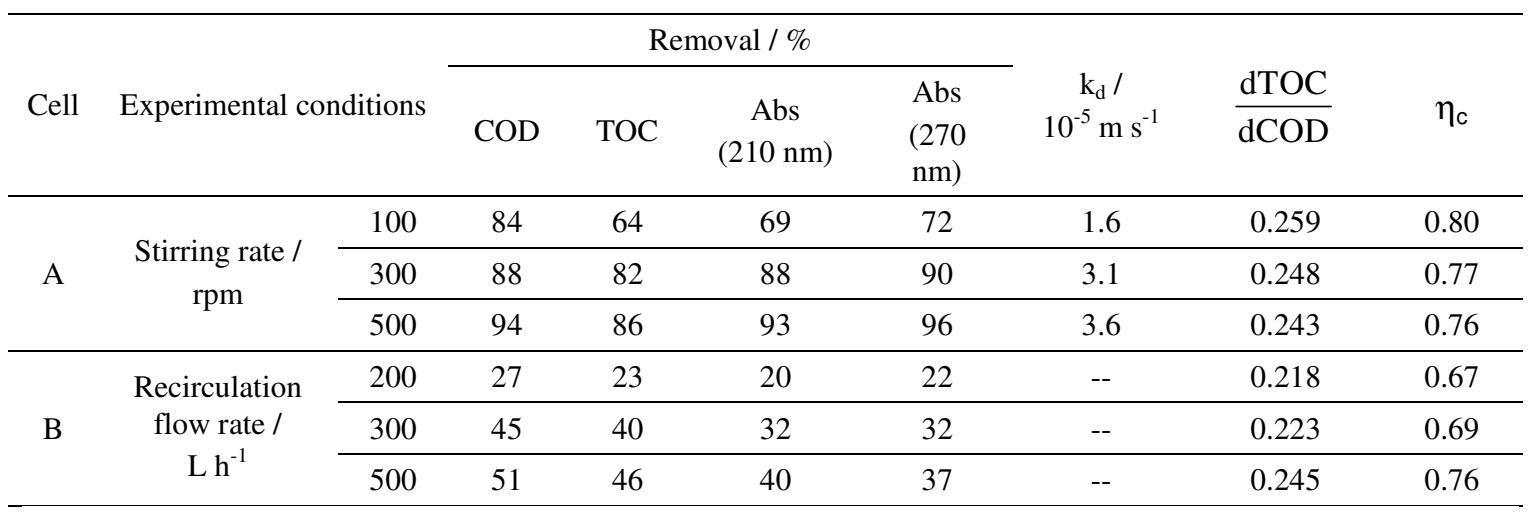

\section{TOC analysis}

The samples collected during the assays were analyzed for the total organic carbon content. Experimental results and the best equations fitted to the experimental points are presented in Fig. 2. TOC removal increases with the stirring speed and with the flow rate, like it was observed for the COD variation. However, the removal of TOC is slower than the removal of COD, meaning that the electrochemical oxidation does not correspond to a complete mineralization. In the case of the highest flow rate tested, there is a clear deviation, after $4 \mathrm{~h}$ assay, from the initial TOC decay trend, meaning that metabolites formed are more resistant to mineralization than phenol.
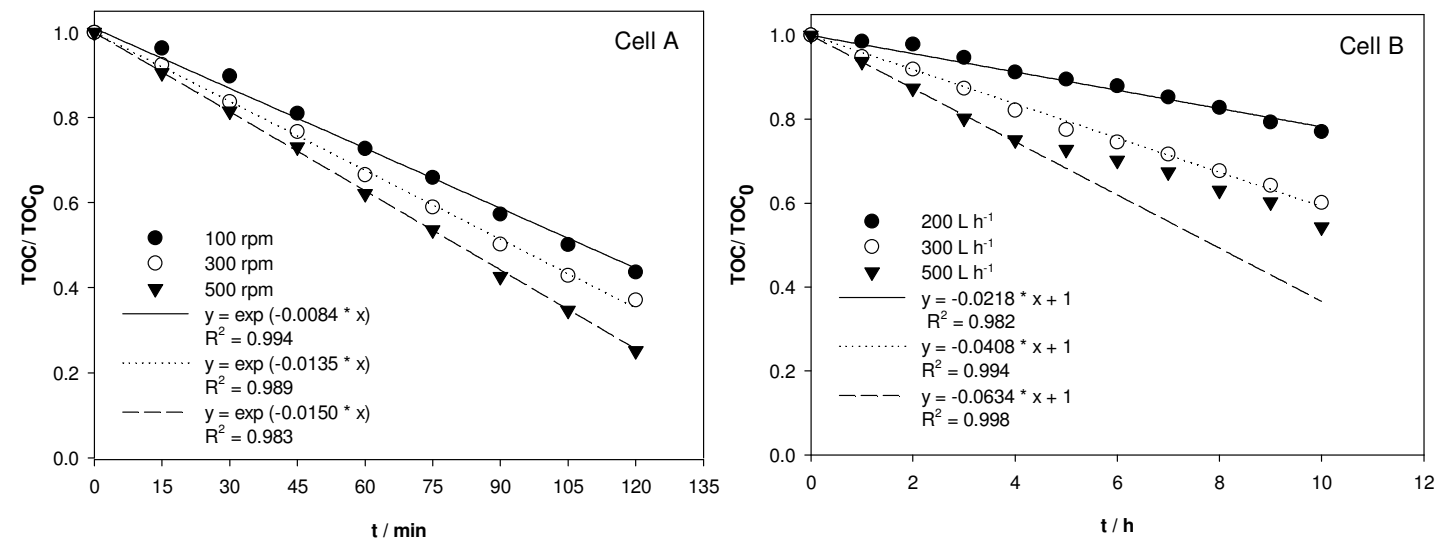

Figure 2. TOC relative removal vs. time for the electrochemical degradation of phenol performed in cell $\mathrm{A}$, at different stirring rates and applied current density of $30 \mathrm{~A} \mathrm{~m}^{-2}$, and in cell $\mathrm{B}$, at different re-circulation flow rates and applied current density of $10 \mathrm{~A}$ $\mathrm{m}^{-2}$. Phenol initial concentration, $300 \mathrm{ppm}$; electrolyte, $0.035 \mathrm{M} \mathrm{Na}_{2} \mathrm{SO}_{4}$ aqueous solution. 


\section{Ultraviolet-Visible spectrophotometry analysis}

In Fig. 3 the relative absorbance removal with time is depicted for some of the experiments performed in both cells. Two different wavelengths, related to maximum of absorbance, were chosen in the ultraviolet region, 210 and $270 \mathrm{~nm}$. In the inserts of Fig. 3, it can also be observed the molecular structure of phenol and its UV-Vis. spectrum.

For the assays performed in both electrochemical cells, the absorbance removal increases with stirring rate and flow rate. However, the decrease in absorbance depends on the wavelength, being, in general, the highest decrease observed for the band with a maximum at $210 \mathrm{~nm}$.
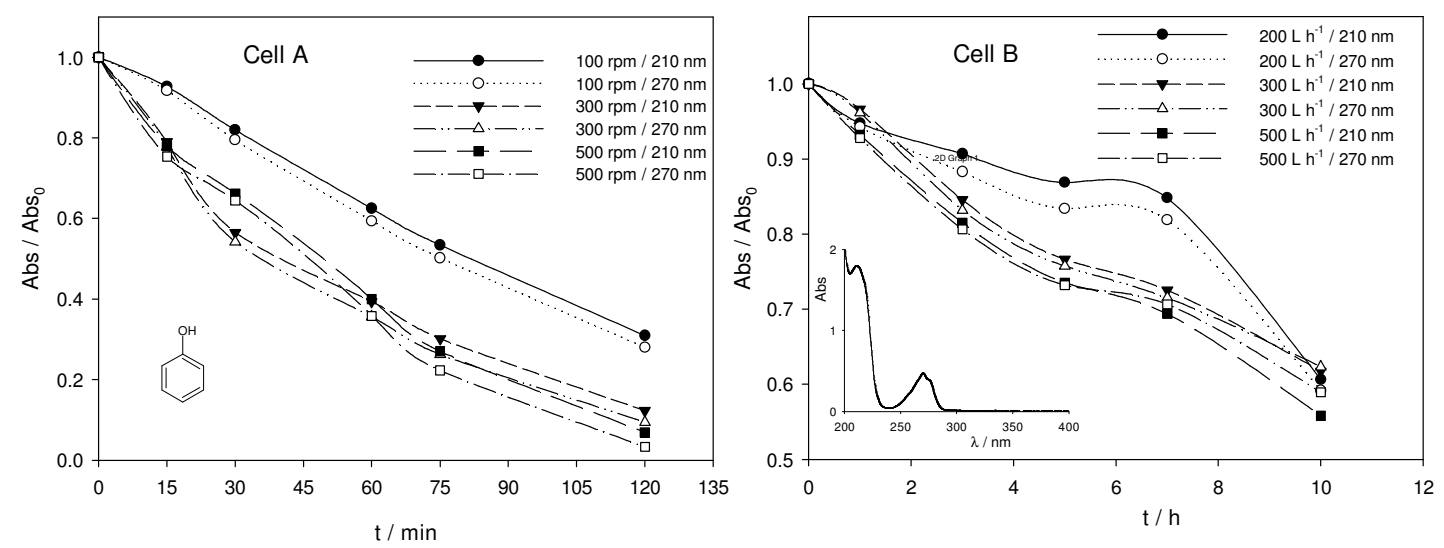

Figure 3. Relative absorbance (Abs) removal vs. time for the electrochemical degradation of phenol performed in cell $\mathrm{A}$, at three different stirring rates and applied current density of $30 \mathrm{~A} \mathrm{~m}^{-2}$, and in cell $\mathrm{B}$, at three different re-circulation flow rates and applied current density of $10 \mathrm{~A} \mathrm{~m}^{-2}$. Phenol initial concentration: $300 \mathrm{ppm}$; electrolyte: $0.035 \mathrm{M} \mathrm{Na}_{2} \mathrm{SO}_{4}$ aqueous solution. Inserts: phenol molecular structure and UV-Vis spectrum.

\section{Combustion efficiency}

According to Pacheco and co-workers [7], the efficiency of the combustion, $\eta_{\mathrm{c}}$, can be estimated from the ratio between the rate of TOC decrease and the rate of COD decrease by:

$$
\eta_{\mathrm{c}}=\frac{32}{12}\left(\frac{\mathrm{n}}{4 \mathrm{x}}\right) \frac{\mathrm{dTOC}}{\mathrm{dCOD}}
$$

where TOC is in $\mathrm{mg}_{\mathrm{C}} / \mathrm{L}, \mathrm{COD}$ in $\mathrm{mg}_{\mathrm{O}_{2}} / \mathrm{L}, \mathrm{n}$ is the number of electrons transferred to the electrode in the process of the complete combustion of the organic solute, and $\mathrm{x}$ is the number of carbon atoms in the organic molecule. For the calculation of $n$ it was assumed that, for phenol, the combustion process is the following:

$$
\mathrm{C}_{6} \mathrm{H}_{6} \mathrm{O}+11 \mathrm{H}_{2} \mathrm{O} \rightarrow 6 \mathrm{CO}_{2}+28 \mathrm{H}^{+}+28 \mathrm{e}^{-}
$$


Plots of TOC vs. COD were then drawn to all assays performed in the different experimental conditions (data not shown), and the slopes thus obtained are listed in Table 1, as well as the combustion efficiencies calculated with eq. (2). Although the values of the combustion efficiencies for the different assays are similar, $\eta_{c}$ presents a tendency to decrease with stirring rate, for the assays performed in cell A. However, in the case of the assays run in cell B, the combustion efficiency increases with the flow rate.

\section{Conclusions}

The electrochemical degradation of phenol was carried out in different hydrodynamic conditions, showing that an increase in turbulence near the electrode's surface is a very important parameter and its control can be used to increase the rate of COD, TOC and absorbance removals. Regarding the mineralization index, measured as combustion efficiency, it slightly decreases with stirring rate in the assays performed in batch conditions and it increases with flow rate in the batch with recirculation experiments.

\section{Acknowledgements}

The financial support of Fundação para a Ciência e a Tecnologia, PDCT/AMB/59392/2004, PDCT/AMB/59388/2004 and PTDC/CTM/64856 /2006 as well as Adamant Technologies, are gratefully acknowledged.

\section{References}

1. G. Busca, S. Berardinelli, C. Resini, L. Arrighi, J. Haz. Mat. 160 (2008) 265-288.

2. M. Fryda, D. Herrmann, L. Schäfer, C.P. Klages, A. Perret, W. Haenni, C. Comninellis, New Diam. Front. Carb. Technol. 9 (1999) 229-240.

3. C.A. Martínez-Huitle, S. Ferro, Chem. Soc. Rev. 35 (2006) 1324-1340.

4. B. Marselli, J. Garcia-Gomez, P.A. Michaud, M.A. Rodrigo, Ch. Comninellis, J. Electrochem. Soc. 150 (2003) D79-D83.

5. M. Panizza, G. Cerisola, Electrochim. Acta 51 (2005) 191-199.

6. A. Morão, A. Lopes, M.T. Pessoa de Amorim, I.C. Gonçalves, Electrochim. Acta 49 (2004) 1587-1595.

7. M.J. Pacheco, A. Morão, A. Lopes, L. Ciríaco, I. Gonçalves, Electrochim. Acta 53 (2007) 629-636.

8. A. Eaton, L. Clesceri, A. Greenberg, Standard Methods for Examination of Water and Wastewater, $21^{\text {st }}$ Ed., APHA, AWWA, WEF, Washington, 2005.

9. M.A. Rodrigo, P.A. Michaud, I. Duo, M. Panizza, G. Cerisola, Ch. Comninellis, J. Electrochem. Soc. 148 (2001) 60-64. 